\title{
Sport as a Tool for International Relations: Case Study of Ugandan Sport Leaders
}

\author{
Hamza KAHWA $^{1} \quad$ Dimitrios GARGALIANOS ${ }^{2} \quad$ Georgia YFANTIDOU $^{3}$
}

\begin{abstract}
While Uganda's participation in sports at international level is growing, the country's relation with other countries is not improving accordingly. The purpose of this study was to investigate whether Uganda sport leaders believe that sport could be used as a tool for the development of international relations of the country. Purposive sampling was used to identify elected and paid sport leaders at all levels in sport organizations in Uganda and invite them to participate in the study. The final sample was 38 sport leaders. The semi-structured interview method was employed. The data was collected with the use of a tape recorder. Recordings were transcribed into written form so that they could be studied in detail, linked with analytic notes and coded. The texts were sent to participants in the study to verify the content. Upon reception of their consent qualitative analysis was performed involving categorizing data and attaching it to the appropriate category. Where necessary, quotes from respondents were used to strengthen the interpretation. The results revealed that Ugandan sport leaders believe that sports: a) play a key role in promoting relations with other countries, b) contribute in creating opportunities for Ugandans to conduct businesses with other countries, c) increase the awareness about the country and d) attract tourists, improving the country's foreign exchange.
\end{abstract}

Keywords - sports, Uganda, international relations, diplomacy, communication

\section{Uluslararası İlişkiler Aracı Olarak Spor: Ugandalı Spor Liderlerinin Örnek Olay İncelemesi}

$\ddot{O} z$

Uganda'nın uluslararası düzeyde spora katılımı artarken, ülkenin diğer ülkelerle ilişkileri aynı düzeyde iyileşmemeltedir. Bu çalışmanın amacı, Uganda spor liderlerinin, sporun ülkenin uluslararası ilişkilerinin geliştirilmesi için bir araç olarak kullanılabileceğine inanıp inanmadığını araştırmaktır. Uganda'daki spor organizasyonlarında her seviyedeki seçilmiş ve ücretli spor liderlerini belirlemek ve onları çalışmaya katılmaya davet etmek için amaçlı örnekleme yöntemi kullanılmıştır. Son noktada örneklem 38 spor liderinden oluşmuştur. Araştırmada yarı yapılandırılmış görüşme yöntemi kullanılmıştır. Veriler bir kayıt cihazı kullanılarak toplandı. Kayıtlar, detaylı bir şekilde çalışılabilmesi, analitik notlarla ilişkilendirilebilmesi ve kodlanabilmesi için yazılı hale getirildi. Metinler, içeriği doğrulamak için araştırmadaki katılımcılara gönderildi. Onaylarının alınması üzerine, verilerin kategorize edilmesini ve uygun kategoriye eklenmesini içeren niteliksel analiz gerçekleştirildi. Gerektiğinde, yorumu güçlendirmek için katılımcılardan alıntılar kullanılmıştır. Sonuçlar Ugandalı spor liderlerinin sporun a) diğer ülkelerle ilişkileri geliştirmede kilit bir rol oynadığına, b) Ugandalıların diğer ülkelerle iş yapmaları için firsatlar yaratmaya katkıda bulunduğuna, c) ülke hakkında farkındalığı artırdığına ve d) tourist çekerek ülkenin döviz durumunu iyileştirdiğine inandıklarını ortaya koymuştur.

Anahtar Kelimeler - Spor, Uganda, Uluslararası ilişkiler, Diplomasi, İletişim.

${ }^{1}$ Social Development through Sport Commission, Uganda Olympic Committee, Uganda, Africa, email: kahwa01@gmail.com

${ }^{2}$ Department of Physical Education \& Sport Science, Democritus University of Thrace, Komotini, Greece, email: dimitris gargalianos@ @otmail.com

${ }^{3}$ Department of Physical Education \& Sport Science, Democritus University of Thrace, Komotini, Greece, email: gifandid@phyed.duth.gr 


\section{INTRODUCTION}

Over time sport developed, evolved and became an efficient way to bridge different cultures, even ones that for some reason (social, political, economic etc.) have been separated (Tony, 2007). Walvin (1984: 67) puts its best by saying that “...organized sport has become a global phenomenon, perhaps second only to industrial capitalism in its scope". The visceral thrill of winning and the pain of defeat evokes transcend all boundaries and build empathy and emotional understanding (Holt, 2012). Such popularity could not escape the attention of the governments, which continually try to find ways to use it for domestic, as well as foreign policy purposes (Johnes, 2008).

This study is guided by Constructivism Theory (Greenwood-Onuf, 1989), which suggests that international relations are socially constructed, and norms play a crucial role in constructing the social environment of states. The theory emphasizes that nonmaterial factors like values, ideas, culture, identities, norms (such as democracy, human rights etc.), shape the international system and help understand better state interests and interactions. Along the same line, many authors (Monnington, 1986; Mearsheimer, 1994; Senn, 1999; Slack, Yuan-min, ChiungTzu \& Hong, 2002) as well as international organizations (i.e., European Union, United Nations etc.) believe that states can influence other states towards building successful relationships not by coercion but by means of persuasion, sport being such a means.

In Uganda, while the participation in sports activities at international level is growing its relations with other countries is not improving accordingly (Ananura, 2004), hence it is not much known at international level (Moore \& Konrad, 2010). The present study investigates the opinions of Ugandan sport leaders on the use of sport as a tool for international relations.

\section{CONCEPTUAL FRAMEWORK}

Formal recognition of international relations as a discipline originated in the political climate prevailing in Europe after World War I, which led to a commitment to develop an approach to international relations, which would ensure an avoidance of a recurrence of war on such a scale (Beacon, 2000). In 1919, Oxford University established the first "chair" (professorship) in International Relations (Carlsnaes \& Beacon, 2012), a branch of political science concerned with relations between nations and primarily with foreign policies (Merriam-Webster Dictionary, 2018). According to Martin and O'Callaghan (2002) international relations concerns the relationships among the various governments of the world, which are interdependently linked to other actors, such as international governmental organizations (IGOs), nongovernmental organizations (NGOs), transnational corporations (TNCs) and influential individuals. Beacon (2000) argued that studies of sport and politics have traditionally presented a number of developing functions of sport as vehicles, through which political objectives might be realized. The hypothesis of this research is that Ugandan sport leaders valorize sport as a tool for international relations of the country.

\section{Sport- Diplomacy}

Sport has been used as an asset of diplomacy since the ancient Greek era (Markovits \& Rensmann, 2010). The Olympic Games (OG) was an opportunity to ease inter-city hostilities through the Olympic Truce (a military cease fire everywhere in the country), which started on the 9th century B.C. During the Truce political congress prevailed and alliances were formed; even death penalties were not enforced (McClancy, 1996).

Modern sport appeared in the middle of the 19th century having an amateur character (DeVoss, 2002), hence its significance for international relations was rather marginal (Coalter, 2010). However, it grew radically in many dimensions, one of them being the number of athletes that participate in the OG (Athens $1896=241$, Berlin $1936=3.963$, Rio $2016=11.237)$. Such an interest in sport could not escape the attention of the governments (Coakley, 2008; Chappelet \& Bayle, 2010). The first to use the OG for government purposes was Adolf Hitler (1936, Berlin) (Tomlinson \& Young, 2006). Few years later, the Soviet Union participated in the 1952 Helsinki OG pursuing prestige at any cost (Henry, 2005). During the Cold War era 
that followed sport was used as yet another arena of confrontation but at the same time provided grounds for diplomacy between the East and West. The most prominent example is the "ping-pong diplomacy" in the early 1970s, which paved the way for Richard Nixon, president of the United States, to visit China for the first time in the history of relations between the two countries (Balyi \& Hamilton, 2004). Following that accomplishment, the US has been very active in the field of sports. Secretary of State, Hilary Clinton, considered sport as an efficient diplomatic tool, which embodied her wider vision of "smart power" diplomacy (Maxim, 2012).

States may also utilize sport to enhance their national prestige, demonstrate their rise on the international stage, and use it to enhance their regional and global influence (Peterson, 2001). De Groot (2011) pointed out the IndiaPakistan's "Cricket Diplomacy", the GreeceTurkey's "Basketball Diplomacy" and the efforts at civil society level from Israelis and Palestinians to build up a common football squad as examples of bilateral reconciliation processes through sporting events. In fact, the so-called "Peres Team for Peace", which was made up of 25 players from both Israel and Palestine, competed at the 2011 Australian Football League International Cup. A real team ethic emerged from that initiative and the players decided to record a song and use it as their national anthem.

There are few areas of development where sport cannot be used as a platform or as a vehicle. Public education, social mobilization, strengthening individual capacity, improving lives, promoting health, preventing diseases, strengthening children, fostering social inclusion, preventing conflict / building peace, fostering gender equity, enhancing inclusion of persons with disabilities and promoting employment and economic development are just some of them (Aman, Mohamed \& OmarFauzee, 2009). The UN Report "Sport as a Tool for Development \& Peace" (UN InterAgency Task Force on Sport for Development \& Peace, 2003: 7), argues that sport has potential to empower, motivate and inspire people from all walks of life. Murray (1999:
50) argued that: “...sports diplomacy exchanges are 'low-risk, low-cost and high profile' and can promote international understanding and friendship, as well as dispel stereotypes and prejudices".

\section{Sport as an international communications platform}

The 4th Fundamental Principle of the Olympic Charter (IOC, 2018) states that, "...the practice of sport is a human right. Every individual must have the possibility of practicing sport, without discrimination of any kind and in the Olympic spirit, which requires mutual understanding with a spirit of friendship, solidarity and fair play". This Principle prompted sport to evolve into a universal language that brings individuals and cultures together in peaceful communication (Mabillard \& Jadi, 2011). Nelson Mandela, former President of South Africa, stated that "...sport is probably the most effective means of communication in the modern world, by passing both verbal and written communication and reaching directly out to billions of people world-wide. There is no doubt that sport is a viable and legitimate way of building friendship between nations" (Maguire, 2005: 89). Coalter (2010) argued that over the past few decades sport has emerged as global mass entertainment and has become one of the most powerful and farreaching communications platforms in the world. This has been possible because global sport events offer the capacity to reach vast numbers of people worldwide. Moreover, sport develops a strong drawing power over fans worldwide affecting and influencing their life through a mediatization of events and competitions that enables them to transcend national, cultural, socio-economic and political boundaries (Balyi \& Hamilton, 2004). Coalter (2010) stated that by extension, high-performance athletes have become global celebrities in their own right, enabling them to serve as powerful ambassadors, spokespeople and role-models for development and peace initiatives.

Sport, international relations and infrastructure development 
Traditionally sports facilities were modest with a capacity of perhaps a few hundred, which, along with the town-hall, the church, etc., served a small community. With the revival of the OG in Athens (1896) the sports facilities evolved into great public buildings regarded as essential and positive elements of civic life (John et al., 2007), prompting the improvement or construction of other physical infrastructure (i.e., telecommunications, transportations systems, etc.) of cities and countries (Milner \& Elliot, 2002). Over the past years investment in sporting infrastructure aimed at attracting tourists, encouraging inward investment and changing the image of the city (Gratton et al., 2005). In the decade leading up to the 2000 Sydney Games, AUS\$ 1.2 billion from the private sector and AUS\$ 2.3 billion from the public sector was invested on infrastructure construction (Owen, 2002). Malaysia spent more than US\$ 55 million to build stadiums in order to host the 16th Commonwealth Games in 1998 (Westhuizen, 2004), the first games ever held in Asia and only the second to be hosted by a developing country (after Jamaica in 1966). The Physical Education and Sports (PES) Department of Uganda plans to massive and systematic capacity building for PES teachers and other personnel at all levels of education and community as required, facilitate and equip the thirty two sports schools as a matter of priority and will develop PES website for e-learning is to alleviate the challenge of instruction materials on PES. Furthermore, the PES will establish a national sports data bank and develop recognition and reward scheme for excelling sports persons to inspire and motivate talented sports persons. It will also improve access to PES provisions at all educational institutions level and community to realize the goals of providing access to quality education and sports for all. The ministry of Education and Sports will rehabilitate six Regional Stadia (Jinja, Mbarara, Kabale, Gulu, Masaka, Mbale) and construct the National High Altitude Training Centre at Teryet in Kapchorwa. Finally the ministry will negotiate partnerships with teacher training institutions for re-tooling of teachers to teach physical education and will increase budget allocation to PES sub-sector to make head way in implementation of Policy provisions (Republic of Uganda, 2021).

\section{Sport as a tool for international business relations}

Given the popular appeal of sport (important for public relations purposes), it is not surprising that companies (especially TNCs) are involved in many of the sport-indevelopment initiatives (mostly as funding partners). Maguire (1999) claimed that modern sport is structured by a political economy in which TNCs play a decisive part and the understanding that business operates more effectively in a climate of peace and stability with a healthy and well-educated workforce. Therefore, many of the sport initiatives are designed with peace, stability, health and education at the forefront.

Furthermore, sport plays an enabling role in facilitating a more secure economic environment. Levermore (2007) argued that this is partly expressed through broad based "macro" programs run by the state and international programs run by the states and international financial institutions (such as the World Bank and International Monetary Fund) sometimes with the help of sports federations. Examples include poverty reduction or national development strategies in Mozambique, Zambia and Belarus (Stradling, 2009).

Another aspect of neo-liberal oriented development associated with the sport/development relationship is the use of sport in social integration initiatives, education, health and defence of human rights. Maguire (1999) argued that some companies use their expertise to help organize, administer and run sport events in order to help train the local workforce. He pointed out that the transferability of skills was apparent in South Africa's 2010 Football World Cup, where Deloitte advertised that their experience with sport events helped them develop enterprise and employment for underemployed black communities so that they could become a more skilled (and flexible) "resource" in the national labour force. Kobierecki (2013) estimated that over 
50,000 people were trained and placed during the event. It is, therefore, contended that economic development builds on these skills, particularly through generating empowerment and fostering organizational and administrative tools that would be useful to entrepreneurship.

The Uganda's Ministry of Education and Sport improves the effectiveness and efficiency in delivery of education and sports services. Uganda received short term capacity building trainings for PES technical personnel conducted by experts in the respective field sent by the German government. The training includes:

\section{- Modern endurance training, \\ - Modern strength training, \\ - $\quad$ Sports physiotherapy, \\ - $\quad$ Modern training in jumps}

Sports Medicine course is planned for next financial year, to empower Uganda's local medical doctors to handle sports related conditions locally. The German government donated electronic timer and wind speed measurement system to enable Uganda to qualify athletes in sprint events for international competition. Uganda will also in due course receive underwater massage equipment donated by the German government; as part of the physiotherapy and strength room to be instituted at Mandela national stadium. PES personnel have participated in PES related workshops, seminars, symposium and conferences both nationally and internationally and the department conducted monitoring and evaluation of PES programmes for quality assurance (Republic of Uganda, 2021).

\section{Soccer as a tool for international relations}

There are approximately 200 million registered soccer players, roughly one out of every 24 people in the world (Hill, 2012). National Geographic has suggested that soccer is the number one sport in over $84 \%$ of the world's countries (FIFA World Magazine, 2011). No other form of popular culture surpasses soccer's huge and participatory passion among its devotees or generates as much commercial revenue at either the club or international level. No wonder then in the fact that the FIFA World Cup is the most watched television program in the world; the number of people around the world who have watched some of the World Cup matches in 2018 reached the highest at 3.572 billion people, nearly half the total world population of 7.6 billion (FIFA, 2018).

Schenk (2011) noted that more than any other sport soccer transcends ethnic and cultural boundaries around the world because it is age / gender independent. It was of no surprise that in 2001 a member of the Swedish Parliament nominated soccer for the Nobel peace prize (Jon, 2013) and national holidays have been declared after victories in soccer (Vamplew, 2012). Frenchman Jules Rimet, founder of the Soccer World Cup and 1956 Nobel peace prize nominee believed that "...soccer could reinforce the ideals of permanent and real peace" (Hough, 2008). Walvin (1984: 97) explained that: “...no one seriously doubts that soccer is the national game, a game described by a critic as having entered the national psyche. For the same reason, soccer is highly political, subject to the stresses and strains of political involvement. In fact, soccer had long been in the political eye. At critical moments, politicians could not afford to stand aloof from the game (not to mention that many are keen fans)".

There are several ways soccer could be applied as a political and diplomatic tool. It could be employed to improve the image of a country, amplify friendships, develop comradeship among nations, promote trade and tourism, integrate minorities and encourage international relations (Samuel, 2012). Mabillard and Jadi (2011: 87) suggested that: "...sports exchanges between the US and Cuba, North Korea, or Iran can break down stereotypes, increase understanding, and confine battles to the playing field rather than the battlefield". A visit of the American national soccer team to Teheran could challenge ingrained stereotypes and historical animosity and help shape beliefs before they are formed. With $21 \%$ of Iran's population less than 24 years old, they would be especially receptive towards such a 
public show of conciliation (Roderick, 2012). Along the same line, when Brazil played a friendly match in war-torn Haiti in 2004, politicians made no attempt to deny the fact that the game was a part of Brazil's efforts to boost chances of gaining a permanent seat in the UN Security Council. In exchange for the Seleção travelling to the Caribbean nation, Haiti agreed to back Brazil in their UN bid, although Haitian lost the football match, this did not seem to bother the Haitian fans, who went on partying long after the Brazilian players had left (Economist, 2004).

\section{Negative impacts of sport}

Although sport is mostly positive in nature there are occasions in which negatively affects individuals and communities. Sport governance issues, manipulation of competition results, violence and abuse in sport, equality and inclusion in sport are some of the issues that increasingly attract public attention. Many of these issues correlate with broader societal challenges and specifically with focus areas of the "2030 Agenda for Sustainable Development" (promotion of human rights, elimination of inequality within and across communities, reduction of violence and harmful practices affecting women, protection of vulnerable communities and children, improvement of access and the inclusion for people with a disability, strengthening of governance to build effective and accountable institutions, etc.) (Commonwealth Secretariat Report, 2015).

\section{Structure of sports in Uganda}

Sport in Uganda is managed by the Ministry of Education and Sport and the Department of Physical Education and Sport (DPES), which has the mandate to develop and coordinate all physical education and sports activities in the country. The milestones and achievements of Department of Physical Education and Sport (PES) of Ministry of Education and Sports are presented bellow. As far as the imrovement of quality and relevance of PES at all level, there were oriented 2,000 Secondary school teachers to teach physical education and sports at secondary level and there was developed the Profile of a Modern Physical
Education (PE) teacher to be implemented by P.E teachers training institutions.

Furthermore, the cooperation with the Chinese government was renewed which resulted into rehabilitation of Mandela national stadium limited as well as Chinese volunteers coming to assist in building human resource locally. It was signed a cooperation agreement with International Association of Athletics Federation (IAAF), which led to standardization of primary schools' sports competitions geared towards talent identification and provision of ageappropriate sports activity. Also, it was signed a cooperation agreement with the German government resulting into the German government sending to Uganda a sports development expert for four years term whose contract expired in September 2013. Finally, it was developed a guideline for conduct of sports competitions for all educational Institutions.

As far as the improvement of equitable access to education and sports, it was ensured that physical education was granted core and compulsory secondary school curriculum subject and physical education curriculum is underway. The department established 32 government aided secondary schools as sports schools (centres of sports excellence) countrywide; with plans to have them well equipped. The DPES organized and coordinated the sports completions for primary, secondary, universities and other tertiary institution. Also, it was initiated a program for sports facilities development such as the rehabilitation of six regional stadia (Jinja, Mbarara, Kabale, Gulu, Masaka, Mbale) and construction of the National High Altitude Training Centre (NHATC). And finally, DPES facilitated National teams to various international competitions such as All Africa Games, World Championships, Olympic Games, World University Games and East Africa Secondary Schools Games among others (Republic of Uganda, 2021).

In 2009, the National Physical Education \& Sports Policy was voted in Parliament, outlining the vision, mission, programs, projects, management arrangements, legal frame work and financing arrangements that 
provide a firm foundation for the development and promotion of a robust physical education and sport sector, as well as the Olympic Movement in Uganda (Sport Administration Manual, 2010). Also responsible organizations for sports in Uganda are: a) the National Council of Sports (NCS), which was established with an Act of Parliament in 1964, under the Ministry of Education and Sports; it serves as an apex organization that coordinates all sports activities in the country, in liaison with National Sports Associations; it is linked to the Supreme Council for Sports in Africa (SCSA) and other relevant sports organizations, b) the Uganda Olympic Committee (UOC, 2010), which was established in 1950 and recognized by the IOC in 1956; its highest organ is the General Assembly and its membership is comprised of 23 affiliated member federations/associations, and c) the Olympic Sport Federations.

\section{METHODOLOGY}

\section{Research method}

The case study research method was employed because it allows in-depth investigation of an individual, group, institution and makes detailed examination of a single subject (Mugenda \& Mugenda, 2003). Rowley (2002) noted that the case study approach is widely used because it provides insights that cannot be achieved otherwise; it permits use of diverse techniques within the same study and helps to generate new understandings and explanations or hypotheses about the problem.

\section{Sample}

This study targeted elected and paid leaders at all levels, working in 43 organizations (National Council of Sport, National Olympic Committee, and Olympic Sport Federations) in Uganda. Purposive sampling was used $(n=38)$ in order to identify elected and paid leaders at all levels, working for at least five years in sport organizations in Uganda, and invite them to participate in the study on a voluntary and anonymous basis. Sampling is the process of selecting the research units of the target population, which are to be included in the study (Sekaran, 2003). Purposive sampling was used for the selection of the managers from different sport federations because: a) people who were not much experienced in the field of sports and international relations (people who had not worked in sports field for at least 5 years) could be excluded and b) it was less time consuming. The results of purposeful sampling are usually expected to be more accurate than those achieved with an alternative form of sampling (Mugenda \& Mugenda, 2003).

\section{Instrument}

The semi-structured interview method was employed with 21 questions as listed bellow.

1) What is your age?

2) What is your highest education level attained?

3) What is your position of responsibility?

4) How long have you been in this position?

5) Do you think soccer plays a key role in promoting political diplomacy?

6) If yes in no. 4 above, in which ways?

7) What are the different ways in which soccer promotes cultural diplomacy?

8) What is your say on the use of soccer as a tool for promoting development and peace?

9) What can be done to promote the use of soccer as a tool for international relations?

10) Do you think cricket plays a key role in promoting political diplomacy?

11) If yes in no. 9 above, in which ways?

12) What are the different ways in which cricket promotes cultural diplomacy?

13) What is your say on the use of cricket as a tool for promoting development and peace?

14) What can be done to promote the use of cricket as a tool for international relations

15) Do you think athletics plays a key role in promoting political diplomacy?

16) If yes in no. 14 above, in which ways? 
17) What are the different ways in which athletics promotes cultural diplomacy?

18) What is your say on the use of athletics as a tool for promoting development and peace?

19) What can be done to promote the use of athletics as a tool for international relations?

20) What are the challenges faced in promoting international relations?

21) What can be done to improve Uganda's relations with other countries through the use of sport?

Validity: The interview guide of the present study was tested for validity by engaging two research experts as suggested by Gay (1996). The following formula was used to test validity index:

Content Validity Index = Number of items regarded relevant by judges Total number of items in the instrument

The interview guide was considered valid, as the generated coefficient was above 0.7 (Amin, 2005).

\section{Data collection}

The data was collected with personal (face to face) communication with each one of the respondents and the use of a tape recorder. The researcher obtained consent in writing from all the participants and their anonymity was observed. Recordings were transcribed into written form and the texts produced were sent to the participants in the study to verify the content. Upon reception of their written consent qualitative analysis was performed involving categorizing data and attaching it to the appropriate category. Where necessary, quotes from respondents were used to strengthen the interpretation. The researcher got an introductory letter from the University to seek necessary permission from different authorities. The letter was presented to the officials of the Uganda Olympic Committee, the National Council of Sports and the Sport Federations to get permission. Cover letters accompanying the interview guide explaining the purpose of the study were distributed directly to the respondents in their respective areas to be filled.

\section{Data analysis}

The data was collected with the use of a tape recorder. Recordings were transcribed into written form so that they could be studied in detail, linked with analytic notes and coded. The texts were sent to participants in the study to verify the content. Upon reception of their consent qualitative analysis was performed involving categorizing data and attaching it to the appropriate category. Where necessary, quotes from respondents were used to strengthen the interpretation.

\section{Limitations of the study}

The study was limited to the people working at the National Council of Sports, the Ugandan Olympic Committee and the Sports Federations of the country. It did not involve people working at sports clubs.

\section{RESULTS AND DISCUSSION}

\section{Demographics}

Regarding the participants all were men, as far as their age five of them (13.6\%) were under 30 years old, $21(55.3 \%)$ were between 30 - 45 and $12(31.6 \%)$ were over 45 years old. The fact that the majority of the respondents were between 30 - 45 years old could be attributed to the nature of Uganda's population, where young people are the majority (UBOS, 2016). Regarding their position in the organization $30(78.9 \%)$ held managerial positions and $8(21.1 \%)$ were assistant managers. Nine (23.7\%) worked in that position for five years, $19(50 \%)$ between 5 - 10 years and $10(26.3 \%)>10$ years.

\section{Qualitative data}

\section{Sport - Diplomacy}

Sport leaders view sports as a tool for winning popularity. They noted that countries like America, Britain, Japan, Germany, Canada and other western powers invest a lot of money in sports activities, mostly football, to increase their respect and popularity on the globe. This is in line with Respondent (9) who noted that: "...world sports have also contributed in influencing politics, and that 
explains the reason why the western countries are interested in winning the World Cup. The winners are considered powerful both politically and sports wise". This point was also argued by Walvin (1984: 97) who explained that: " ...no one seriously doubts that football is the national game, a game described by one critic as having entered the national psyche. For the same reason, football is highly political, subject to the stresses and strains of political involvement. In fact, football had long been in the political eye. At critical moments, politicians could not afford to stand aloof from the game (quite apart from the fact that many are keen fans)".

Sport leaders noted that sports provide platforms for diplomats, intellectuals and politicians to discuss issues affecting the participating countries. They noted that sports act as a starting point for other businesses or deals between countries. Respondent (27) commented that: "...sports increases the chances of interactions between citizens and the businessmen from different countries. This therefore increases the chances of sharing ideas on how to work together or transact businesses between borders". Respondent (28) commented that: “...sports contribute in providing channels for diplomatic initiatives, thereby providing chances for improving relations between hostile governments. This is achieved during the process of organizing sports events, whereby administrators of different participating countries come together leading to increased opportunities of creating friendships and, therefore, creating opportunities for solving grudges that may be standing between participating countries". In support of this finding, Peterson (2001) argued that states may also utilize sport to enhance their national prestige, demonstrate their rise on the international stage, and make use of soft power to extend their regional and global influence.

Sport as an international communications platform

Sport leaders cited the relevancy of sports for promoting political agendas whereby sports platforms can be used to communicate issues of interest to the host country or funding agent. They claim that this has been used by some countries to promote themselves across continents and extend their relationships. This also promotes the learning of guests about the interests of the hosting country and therefore bringing constructivism theory in play. This is in line with Respondent (14) who noted that: “...sports act as a platform for communicating political events. Most sports events and sports media houses are used as platforms for promoting political interests of the hosting countries". This was also supported by Coalter (2010) who argued that over the past few decades sport has emerged as one of the most powerful and far-reaching communications platforms in the world because global sport events offer the capacity to reach vast numbers of people worldwide. $\mathrm{He}$ further stated that by extension, highperformance athletes have become global celebrities in their own right, enabling them to serve as powerful ambassadors, spokespeople and role-models for development and peace initiatives.

Sport leaders agreed that sports can play a key role in promoting international recognition mostly among countries that are not much known (i.e., developing countries, new states). This usually happens after participating in global sports events or getting an international sport celebrity from such a country. This can promote learning of morals, values and attitudes of people from emerging states and therefore necessitating the relevancy of constructivism theory. Respondent (29) commented that: "...existence of some countries can easily be realized through participation in sports and this gives the reason why some countries invest much more money in sports events than others. Most developing countries for example in Africa and the Caribbean can easily popularize their presence and improve their relations with other states through participation in sport". Respondent (30) commented that: 
"...politicians in most countries gain from sports activities that take place and this allows sport officials to have a great influence on such politicians ... this makes sport a political matter". This was also supported by Eden (2003) who noted that participation in sport is a very important aspect of sports' connections with international relations. Although at face value sport is a competition among athletes, its international dimension is more important than the competition among nations.

\section{Sport, international relations and infrastructure development}

Sport leaders accredited sport as a source of unity while noting that political problems can be resolved through organizing of sports events. They further noted that they have been able to extend Ugandans friendship to countries that have not been friends before and this helped in bringing together the politicians, diplomats and citizens of the different countries to be in touch with Ugandans. In such process, constructivism theory applies because people keep learning from one another and as a result it becomes easy for one to travel or work in different countries. This is in line with Respondent (13) who noted that: “...sports help in promoting peace through uniting people of different cultures. More people from all parts of the world usually meet during athletes and soccer games as compared to other political or economic meetings".

Sport leaders agreed that Uganda has not gained much international relations as a result of sports due to limited and underdeveloped sports facilities, which affected the number of citizens participating in sports training and the quality of training they receive. This is in line with Respondent (15) who noted that: “...in Uganda, there is limited exposure to most sport games other than football, netball, rugby and cricket, which is mostly attributed to limited funding allocated by the government to sports facilities and sports equipment. This has therefore limited the impact of sports on international relations", with Respondent (16) who noted that: “...though Uganda has gained many relations internationally as a result of sport, it has been limited by the challenge of few sports facilities in the country. For example, the country has only one football stadium that is built up to national standards" and with Respondent (17) who noted that: "...Ugandan budget has never allocated enough funds to sports ministry for either human resource development or facility development; this has therefore affected the effect of sport on international relations".

Sport as a tool for international business relations

Despite its long-time neglect by the international relations academic society, sport's role as a rallying point for political ideology and its universal appeal provide a compelling argument for its importance to international relations (Coalter, 2010). Most respondents accredited sports for developing the leisure industry as most people travel from countries to other countries to watch international games. Sport leaders further realized the use of sport mostly soccer in hangout places like bars, restaurants and others as a way of attracting customers. According to sport leaders, this helps in promoting popularity of countries that appear much in sports games and therefore promoting international relations. This is in line with Respondent (10) who noted that: “...sports have played a key role in promoting the entertainment sector. Most people spend their leisure time in watching football matches, which creates income to the country. Countries which have invested much in sports have developed international media houses, which help in developing their tourism industries". Respondent (2) also noted that: "...sports play a key role in shaping both regional and continental engagement at both citizen and government level". This argument was also supported by Andrzejewski, Chmura, Pluta, Strzelczyk and Kasprzak (2013) who claimed that sport is the most significant part 
of the global entertainment industry and the FIFA World Cup Tournament, along with the OG are the most watched TV programs in the world. Darby (2003), referred that Africa has made its presence felt, and it is perhaps in international football that the continent's sports stars have made their biggest impact. The World Cup, the Olympic football tournament, and FIFA's underage competitions have been enriched by the presence of African nations. African performances at these competitions show that Africa's most vibrant football nations have emerged as credible challengers to the traditional preeminence of South America and Europe.

Sport leaders agreed that sports can be used for mobilizing resources from large groups of people. They argued that it has been mostly common in athletic competitions regionally and nationally, thereby increasing the relevancy of sport in community mobilizations. However, constructivism theory is mostly correlated with learning and is silent on resource mobilization after knowledge acquisition. This is also in line with Respondent (18) who noted that: "...sport has been used by most countries as platforms for public education and social mobilization ... most countries have been able to mobilize resources for funding social programs through the use of sports events mostly athletics". This was also supported by Coalter (2010) who argued that over the past few decades sport has emerged as global mass entertainment and has become one of the most powerful and far-reaching communication platforms in the world. This has been possible because global sport events offer the capacity to reach vast numbers of people worldwide; they are effective platforms for public education and social mobilization.

Coalter (2010) stated that high-performance athletes have become global celebrities in their own right, enabling them to serve as powerful ambassadors, spokespeople and role-models for development and peace initiatives. This helps in making the country known and popular in different parts of the world. Respondent (19) commented that: "...sport has enabled individuals to become global; celebrities and thereby selling the names of their home country to the outside world. This also promotes the country to earn from such celebrities through taxing the money they get by participating in international, deals/activities. For example, Kiprotich earned foreign exchange for the country. However, in Ugandans case most people do not respect sports as a career and this has denied the country an opportunity to get many celebrities and therefore limiting the opportunity to earn much foreign exchange". Respondent (20) also noted that: “... sport has helped many countries to become known globally, for example Brazil. Many countries have got interest in creating relationships with Brazil after knowing it through sports because the country exports a number of celebrities who work in other countries as footballers". This was also supported by the UN InterAgency Task Force on Sport for Development \& Peace (2003), which argued that sport consistently empowers, motivates and inspires individuals and their communities in a way that promotes hope and a positive outlook for the future, ingredients that are essential to the success of all development and peace endeavours.

\section{Soccer as a tool for international relations}

Most respondents noted that soccer plays a key role in promoting international relations, while others recognized that they have created a number of friends both domestically and internationally because of soccer. Sport leaders understand the power of soccer and other games in uniting countries of different or same regions and continents together. Respondent (1) noted that: "...soccer plays a key role at both national and international level. It has helped in promoting relations between Uganda and other countries through friendly matches and international leagues like CECAFA, African Cup and others".

Sport leaders noted that sports events are used as symbols for the ending of disputes between countries and therefore the beginning of good relations between them. They further noted that without sport, it could be difficult for countries and their citizens to engage in friendly meetings with citizen participation in consideration as compared to when there is sport. Respondent (25) commented that 
"...friendly sports matches between different countries can be used as a symbol for solving misunderstandings. This can help in promoting international relations and this is mostly done through the use of sport or athletics. Respondent (26) commented that "...friendships between dignitaries from different countries are also achieved through sports events. This usually happens during mega sports matches like the World Cup and other continental level competitions. Such friendships help in promoting business and political transactions between different countries". In support of this finding, Balyi and Hamilton; (2004) noted that during the Cold War sport proved to be a useful and powerful tool to reach peaceful relations and foster mutual understanding between the East and West.

Sport leaders noted that people who participate in regional, national and international games create friends from within and outside their country of origin and thereby getting empowered. Through such connections, sport acts as a platform for international relations which plays a key role in the country's growth and development. This supports constructivism theory because growth and development can only take place when learning is taking place. Respondent (21) commented that: "...sports helps in empowering people by showcasing what they can and what they cannot do. The quality of players can easily be judged by the public during the sports event and this helps in empowering talented players to sell their skills outside their countries of origin". Respondent (22) commented that: “...many people have got recognized in the media globally through sports and this has enabled them to participate in international events. Sport continues to be a key driver of the media industry which joins the world together and enables relations to be made between different countries". This is in line with the UN Inter-Agency Task Force on Sport for Development \& Peace (2003), which argued that sport has potential to empower, motivate and inspire people from all walks of life. Sport is inherently about drawing on, developing and showcasing people's strengths and capacities. It inspires individuals and their communities in a way that promotes hope and a positive outlook for the future, ingredients that are essential to the success of all development and peace endeavours.

Sport leaders noted that sports create employment opportunities for different groups of people. This can happen in the form of contracts for international players that are hired by other countries and also jobs are created when hosting regional or international sports games like CECAFA and World Cup, which thereby help in uniting people from different parts of the world and therefore promoting international relations. Respondent (12) commented that: "...sports promote development through increasing the employment of football players on international deals and for long periods of time. This acts as a source of earning for both the player and the country in the form of taxes" ...

Sport leaders noted that sports reduce the challenge of unemployment in the country by allowing people to work in different countries or working in their own country but in a game involving other countries and thereby creating opportunities for creating relations between them. Respondent (23) commented that: "...sports events contribute in creating employment opportunities for the youth. This mostly applies in mega sport events like World Cup and African Cup, where big number of people are trained to work in the event. The skills attained by such people during the event can also help in developing the country". Respondent (24) commented that: "...sport has played a key in reducing the rate or level of unemployment in different countries as most of the players, for example in football, are employed at club level. This helps in sharpening their skills that enables them to play at country level. This thereafter helps in promoting international relations". This is in line with Kobierecki (2013), who noted that during the 2010 World Cup in South Africa over 50,000 people were trained and assigned to jobs.

Sport leaders noted that sports can shape what people from other countries think about a certain country, for example countries which win the Soccer World Cup are considered to be rich. Respondent (31) commented that: 
Kahwa, H., Gargalianos, D. \& Yfantidou G. (2021). Sport as a Tool for International Relations: Case Study of Ugandan Sport Leaders. International Journal of Recreation and Sports Science, 5 (1), 5-18. https://doi.org/10.46463/ijrss.853864

“...sports and international relations are related in such a way that the more the country participates in international games, the more it is known ... countries which win such games are more popular". It could be stated that the mutual influence between sport and international relations was initiated when sport gained vast popularity, which allowed politicians to gain from it and sometimes even sport officials to influence politicians.

\section{Negative impacts of sport}

Sport leaders were aware that sports can also create bad relations between countries. They argued that this can start with fights among the players during a game, which may deteriorate relations between citizens on both sides. This is in line with the view of Respondent (4) who noted that: “...sport is both a cause of friendship between people but at the same time a worsening factor". This view is in line with Peterson (2001) who argued that it is hard to establish that sport naturally leads to high-level meetings between political and sport leaders. Respondent (3) also noted that: “... soccer is associated not only with positive benefits, it can also contribute to inflicting wars between countries affecting political diplomacy, as it happened, for example, between Honduras and $\mathrm{El}$ Salvador, in 1970 World Cup".

\section{CONCLUSIONS}

This research investigated the opinions of Ugandan sport leaders on the use of sport as a tool for international relations of the country. The results of this study revealed that Ugandan sport leaders believe that sports play a key role in promoting relations with other countries and contribute to creating opportunities for Ugandans to conduct businesses with other countries. Furthermore, sports increase the awareness about the country and attract tourists, therefore improving the country's foreign exchange. Hence, the research hypothesis was confirmed. However, they also noted that a lot still needs to be done in order for Uganda's sport industry to contribute more efficiently in promoting its relations with other states and a future reservh could investigate the future plans of Ministry and their effectiveness to the society.

\section{REFERENCES}

Aman, M. S., Mohamed, M., \& Omar-Fauzee, M. S. (2009). Sport for all and elite sport: Underlining values and aims for government involvement via leisure policy. European journal of social sciences, 9(4), 659-668.

Amin, M. A. (2005). Social science research: Conception, methodology \& analysis. Kampala: Makerere University Press.

Ananura, E. K. (2004). Factors that affect the development of women football in Uganda. Master thesis, Kyambogo University, Kampala.

Andrzejewski, M., Chmura, J., Pluta, B., Strzelczyk, R., \& Kasprzak, A. (2013). Analysis of sprinting activities of professional soccer players. The Journal of Strength \& Conditioning Research, 27(8), 2134-2140. https://doi.org/10.1519/JSC.0b013e31827 $9423 \mathrm{e}$

Balyi, I., \& Hamilton, A. (2004). Long-term athlete development: Trainability in childhood and adolescence. Olympic Coach, 16(1), 4-9.

Carlsnaes, M., \& Beacon, M. (2012). The effect of hosting the Olympics on national image: An analysis of US newspaper coverage of host countries with reputation problems. Graduate Theses and Dissertations. Paper 11658, Iowa State University.

Cha, V. D. (2009). A theory of sport and politics. The International Journal of the History of Sport,26(11), 1581-1610. https://doi.org/10.1080/095233609031329 72

Chappell, R. (2008). Sport in postcolonial Uganda. Journal of Sport and Social Issues, 32(2), 177-198. https://doi.org/10.1177/019372350831519 5

Chappelet, J. L., \& Bayle, E. (2010). Strategic and performance management of Olympic sport organizations. Champaign: Human Kinetics. 
Kahwa, H., Gargalianos, D. \& Yfantidou G. (2021). Sport as a Tool for International Relations: Case Study of Ugandan Sport Leaders. International Journal of Recreation and Sports Science, 5 (1), 5-18. https://doi.org/10.46463/ijrss.853864

Coalter, F. (2010). The politics of sport-fordevelopment: Limited focus programmes and broad gauge problems? International review for the sociology of sport, 45(3), 295-314. https://doi.org/10.1177/101269021036679 1

Darby, P. (2003). Africa, the FIFA Presidency, and the Governance of World Football: 1974, 1998, and 2002. Africa Today, 3-24. https://doi.org/10.1353/at.2003.0055

De Groot, G. (2011). Sport and politics: Sometimes a good mix. Center for Security Studies, ETH Zurich. Accessed October 2017. https://css.ethz.ch/en/services/digitallibrary/articles/article.html/126615/pdf

DeVoss, K. (2002). Sport, policy and politics: A comparative analysis. New York: Routledge.

Gay, L. R. (1996). Qualitative - quantitative research methodology: Exploring the interactive continuum. Upper Saddle River, NJ: Prentice-Hall.

Greenwood-Onuf, N. (1989). World of our making: Rules and rule in social theory and international relations. Columbia, SC: University of South Carolina Press.

Henry, I. P. (2005). Sport and multiculturalism: A European perspective. Barcelona: Centre d'Etudis, Olímpics.

Kobierecki, M. M. (2013). Sport in International Relations. Expectations, Possibilities and Effects. International Studies: Interdisciplinary Political and Cultural Journal (IS), 15(1), 49-74. https://doi.org/10.2478/ipcj-2013-0004

Maguire, B. (1999). Rugby and the South African Nation: Sport, culture, politics, and power in the old and new South Africa. International Studies in the History of Sport. Manchester: Manchester University Press.

Maguire, J. A. (2005). Power and global sport: Zones of prestige, emulation and resistance. New York: Routledge.

Markovits, A. S., \& Rensmann, L. (2010). Gaming the world: How sports are reshaping global politics and culture. Princeton
University

Press. https://doi.org/10.1515/9781400834662

Moore, M. E., \& Konrad, A. M. (2010). A reflection of the contributions of women in sport management: Advancing the representation through HRM structures. Gender in Management: An International Journal, 25(2), 92-105. https://doi.org/10.1108/175424110110262 85

National Council of Sports - NCS (1964). Act of Parliament. Accessed March 5, 2018. http://www.ncs.ug/ncs.ug

Peterson, P. (2001). Sporting nationalisms: Identity, ethnicity, immigration and assimilation. London: Cass.

Pfeifer, C., \& Cornelißen, T. (2010). The impact of participation in sports on educational attainment-New evidence from Germany. Economics of Education Review, 29(1), 94-103. https://doi.org/10.1016/j.econedurev.2009. 04.002

Republic of Uganda (2021). Department of Physical Education and Sports. Accessed March 5, 2021. http://www.education.go.ug/

Stradling, J. (2009). More than a game: When sport and history collide. Accessed February 7, 2017. http://trove.nla.gov.au/work/32127129?sel ectedversion $=N B D 44357097$

Uganda Olympic Committee (2010). Constitution. Accessed February 2, 2017. https://www.olympic.org/uganda

United Nations Inter-Agency Task Force on Sport for Development \& Peace (2003). "Sport for Development and Peace: Towards Achieving the Millennium Development Goals." Accessed April 5, 2017. https://www.unicef.org/sports/reportE.pdf.

Walvin, J. (1984). Sport, social history and the historian. The International Journal of the History of Sport, 1(1), 5-13. https://doi.org/10.1080/026493784087135 34 